DOI: https://doi.org/10.32353/acfs.3.2021.03

UDK 343.85

Olena Agapova,

Head of the Department of International Cooperation and Work with Foreigners of National Scientific Center «Hon. Prof. M.S.Bokarius Forensic Science Institute», PhD in Law. ORCID: https://orcid.org/0000-0003-1024-0238

e-mail: agapova-lena-@ukr.net

Yuliia Shpak,

Researcher of National Scientific Center «Hon. Prof. M. S. Bokarius Forensic Science Institute». ORCID: https://orcid.org/0000-0001-5670-9893

e-mail: ushpak97@gmail.com

\section{Gender Imbalance in the Field of Providing Forensic Services for Justice: Current Situation in Ukraine and International Experience}

The article is devoted to the problem of gender inequality in general and in the field of providing forensic services for justice, in particular, the problem of vertical segregation of labor. The article analyzes the national and international legal acts to overcome gender inequality in various spheres of public life. The activity of central executive bodies on the improvement of the position of women in society and the impact of such activity on the position of women in the field of justice is studied. Indicators displaying the possible vertical segregation of labor in management positions in state specialized institutions of Ukraine are given. Examples of international organizations whose activities are aimed at improving the position of women in the field of expert justice are introduced.

Keywords: gender gap, gender equality, providing forensic services for justice, international non-governmental organizations.

Introduction. Gender equality is one of the most important human rights, it plays a key role in ensuring the peace and well-being of society, as well as the full realization of human potential through sustainable development. ${ }^{1}$ Gender inequality is one of the indicators of the lack of protection of human rights in the state, the low level of legal awareness of the population and the formal nature of the functioning of civil society institutions. Gender equality is one of the ground principles of human rights, the basis of democratic development of states and the world community. ${ }^{2}$ There are no developed democracies with high rates of gender inequality, as it is a brake on any social development.

The problem of gender inequality is not new or unexplored, but it still holds the position of one of the most common factors of negative impact on society in many areas. The manifestations of gender inequality in the sphere of labor relations are quite striking, which, for example, consist in an unjustified difference in wages ${ }^{3}$, as well as in the scientific field due to existing stereotypes. ${ }^{4}$ Currently, the problem of gender inequality is pertinent in the field of providing forensic services for justice.

Гендерное равенство. Организация Объединённых Наций. 2021. URL: https:/ / www.un.org/ $\mathrm{ru} /$ sections/issues-depth/gender-equality/.

2 Камінська Н. В., Чернявський С. С., Перунова О. С. Засади розуміння тендеру та гендерної рівності. 2020. URL: https://www.dsns.gov.ua/files/2020/5/20/112/\%D0\%9B\%D0\%B5\%D0\% BA \%D1\%86\%D1\%96\%D1\%8F_1.pdf.

3 Черба В. М., Ромашко I. Ю.Гендерна нерівність на ринку праці України. Ефективна економіка. 2016. № 5. URL: http://nbuv.gov.ua/UJRN/efek_2016_5_40

4 Ісакова Н. Б. Гендерний паритет у науці: тенденції в світі та в Україні. Наука та наукознавство. 2018. № 2. С. 68-90.

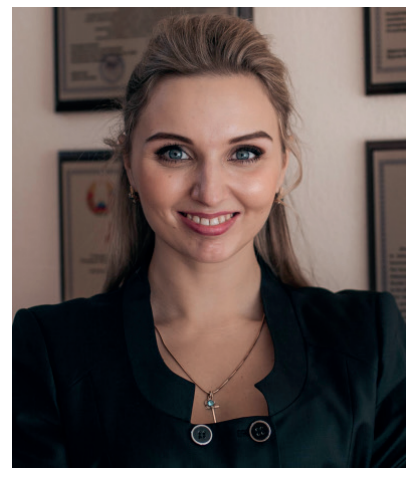

Agapova

Olena

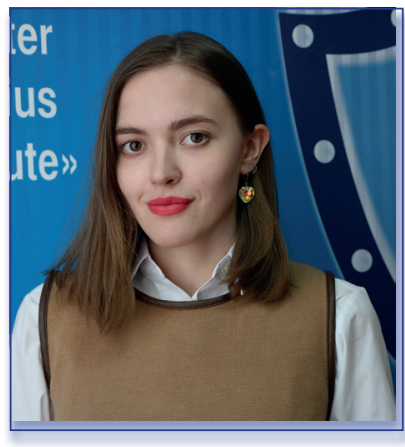

Shpak

Yuliia 


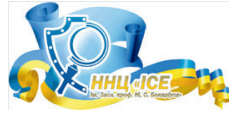

O. Agapova, Yu. Shpak

GENDER IMBALANCE IN THE FIELD OF PROVIDING FORENSIC SERVICES FOR JUSTICE: CURRENT SITUATION IN UKRAINE AND INTERNATIONAL EXPERIENCE

Abstract. The article is dedicated to the issue of gender inequality in general, and in particular in the field of forensic expert support of justice, including the problem of vertical segregation of labor in leadership positions in state specialized institutions of Ukraine. The article outlines possible reasons for the existence of gender imbalance in the form of vertical segregation of labor in leadership positions in the field of employment and in the field of forensic expert support of justice, as well as examples of gender inequality manifestations. An analysis of previous researches of distinguished women scientists and representatives of civil society institutions as to the problem of gender imbalance in the field of education, professional selfdetermination and career growth has been carried out. A specific focus is drawn to particular manifestations of gender imbalance in science. At the same time, the analysis of legal regulations of national and international significance on counteraction to gender inequality in different areas of public life has been considered. The activity of central executive agencies regarding advancement of women in society and influence of initiated programs on counteraction to gender imbalance in the field of forensic expert support of justice is studied. Statistics on manifestations of possible vertical segregation of labor in leadership positions in state specialized institutions of Ukraine is provided. Examples of international organizations which activity has a wide range of influence and the ones which activity is aimed at improving the state of women forensic experts in the field of forensic expert support are outlined. The experience of such organizations for preventing and overcoming gender imbalance, as well as specific proposals for solving this problem are taken into consideration

Key words: gender imbalance, gender equality, forensic expert support of justice, international non-governmental organizations.
GenderImbalancein the FieldofProviding Forensic Services for Justice:Current Situationin Ukraine and International Experience

Analysis of publications where this problem solution is initiated. The problem of gender imbalance has been studied in various aspects by a number of scientists. O.R. Dashkovskaya concluded that gender equality as one of the types of equality should be built considering all possible dimensions that can compensate for the shortcomings of the formality of legal equality. ${ }^{5}$ The consultant of the Office of the Government Commissioner for Gender Policy G.G. Zhukovskaya, member of the NATO Civil Society Advisory Group O.I. Suslova and the Government Commissioner for Gender Policy K.B. Levchenko stated that imperfect gender statistics do not allow to observe and analyse the conditions of ensuring equal access to quality education, professional self-determination and career growth. Gender equality should provide equal opportunities for all participants in the educational process in Ukraine an access the available positive outcomes in the education and science. ${ }^{6,7}$ We agree with the opinion of the head of the Department of Gender Equality of the Ministry of Internal Affairs O.S. Perunova, who aptly noted that the foundation of further social progress is the equality of all its members. It is inadmissible for a democratic state to completely or partially exclude the part of population from making important state and public decisions. ${ }^{8}$ N.V. Kaminska and M.M. Sveshnikova thoroughly researched the activities of international organizations to protect women's rights in various areas. ${ }^{9}$ The activity of V.M. Troyan on the organizing of international conferences "Women in Science and Education: Past, Present, Future" and on publishing its materials deserves attention ${ }^{10}$. This international conference was the first platform to present E.M. Libanova's made a presentation on Women's access to the labor market, ane later became the first woman-member of the Presidium of the National Academy of Sciences of Ukraine ${ }^{11}$. However, the topic of gender imbalance in the field providing forensic services for justice remained out of the attention of researchers.

Aim. The purpose of the article is to highlight the problem of gender imbalance in the field of providing forensic services for justice, to pay attention to the problem, to study international experience and to find ways of solving the problem in Ukraine.

Results and discussion. Guarantees of equality and non-discrimination are defined in a number of normative acts of international law, which include: the Universal Declaration of Human Rights, ${ }^{12}$ International Covenant on

Дашковська О. Р. Принцип гендерної рівності: поняття, витоки і роль на сучасному етапі розвитку суспільства. Порівняльно-аналітичне право. 2014. № 5. С. 23.

6 Катерина Левченко, Галина Жуковська. Інституціональний механізм реалізації державної політики забезпечення рівних прав та можливостей жінок і чоловіків: актуальний стан, проблеми, перспективи розвитку. URL: https://www.publichne-pravo. com.ua/files/31/23.pdf

Жуковська Г. Г., Левченко К. Б., Остапенко О. О., Суслова О. І. Гендерна політика в нормативно-правових документах. 2016. URL: https://www.kmu.gov.ua/storage/app/ sites/1/18\%20-\%20Department/18\%20-\%20PDF/02.2021/genderna-polityka.pdf.

8 Перунова О. С. Гендерно-обумовлене насильство: поняття та ознаки. Правове життя сучасної України : у 3 т. : матеріали Міжнар. наук.-практ. конф. (м. Одеса, 15 трав. 2020 р.) / відп. ред. М. Р. Аракелян. Одеса : Гельветика, 2020. Т. 1. С. 219.

9 Камінська Н., Свєшнікова М. Діяльність міжнародних організацій у сфері забезпечення гендерної рівності. URL: https://scholar.google.com.ua/citations?user=yeAhqYsAAAAJ\&hl= ru\#d=gs_md_cita-d\&u=\%2Fcitations\%3Fview_op\%3Dview_citation $\% 26 \mathrm{hl} \% 3 \mathrm{Dru} \% 26 \mathrm{user} \% 3 \mathrm{Dy}$ eAhqYsAAAAJ\%26cstart\%3D20\%26pagesize\%3D80\%26citation_for_view\%3DyeAhqYsAAAAJ \%3ACHSYGLWDkRkC\%26tzom\%3D-180.

10 Жінка в науці та освіті: минуле, сучасність, майбутне. Матеріали Міжнародної науковопрактичної конференції. К.: 1999, 2002, 2005, 2008, 2011. ISBN 966-95382-2-X; ISBN 966-953823-X; ISBN 966-9582-7-0; ISBN 978-617-615-007-7.

11 Лібанова Е.М., Макарова О.В. Доступ жінок до ринку праці: ситуація сьогодення та можливості роз ширення. Мат. нац. тристоронньої конф. “Жінки на ринку праці України”. K., 1998.

12 Загальна декларація прав людини URL: https://zakon.rada.gov.ua/laws/ show/995_015\#Text. 
Civil and Political Rights ${ }^{13}$, International Covenant on Economic, Social and Cultural Rights ${ }^{14}$, United Nations Convention on the Elimination of All Forms of Discrimination against Women ${ }^{15}$, Convention for the Protection of Human Rights and Fundamental Freedoms ${ }^{16}$, European Social Charter ${ }^{17}$, etc. In addition to these acts, there acts aimed at addressing a narrower range of issues related to overcoming gender imbalances. For instance, Council Directive 2000/78/EC establishing a common framework for equal treatment in employment and occupation (27 November 2000) ${ }^{18}$, Directive 2006/54/ EC of the European Parliament and of the Council on the implementation of the principle of equal opportunities and equal treatment of men and women in matters of employment and occupation (new version) (5 July 2006) ${ }^{19}$, Concluding Observations to the Eighth Periodic Report of Ukraine on Ukraine's Implementation of the UN Convention on the Elimination of All Forms of Discrimination against Women, prepared by the Committee on the Elimination of Discrimination against Women ${ }^{20}$ etc.

Ensuring the equal rights for women and men is guaranteed by similar provisions of Ukrainian legislation that meets international standards. The Constitution of Ukraine states in Article 24: "There may be no privileges or restrictions on the grounds of race, color, political, religious or other beliefs, sex, ethnic and social origin, property status, place of residence, language or other grounds. Equality of women's and men's rights is ensured by providing women with equal opportunities with men in socio-political and cultural activities, in education and training, in work and remuneration for it... ${ }^{21}$. In 2005, the Law of Ukraine "On Ensuring Equal Rights and Opportunities for Women and Men" was adopted and it provided the definition of the main terms, the main directions of state gender policy, the authorities responsible for its implementation, the structural elements of policy to ensure the parity of women and men in all spheres of life and more ${ }^{22}$. Discrimination in the labor relations is prohibited by the Labor Code, Article 2-1 states that "Any discrimination in the labor relations is prohibited, in particular violation of the principle of equality of rights and opportunities, direct or indirect restriction of workers' rights depending on race, color , political, religious and other beliefs, gender, gender identity, sexual orientation, ethnic, social and foreign origin, age, health status, disability, suspicion or presence of HIV/AIDS, marital and property status, family responsibilities...n"

13 Міжнародний пакт про громадянські і політичні права. URL: https:/ /zakon.rada.gov.ua/ laws/show/995_043\#Text.

14 Міжнародний пакт про економічні, соціальні і культурні права. URL: https:/ /zakon.rada. gov.ua/laws/show/995_042\#Text.

15 Конвенція Організації Об'єднаних Націй про ліквідацію всіх форм дискримінації щодо жінок. URL: https://zakon.rada.gov.ua/laws/show/995_207\#Text.

16 Конвенція про захист прав людини і основоположних свобод. URL: https:/ / zakon.rada.gov. ua/laws/show/995_004\#Text.

17 Європейська соціальна хартія. URL: https://zakon.rada.gov.ua/laws/show/994_062\#Text.

18 Директива Ради 2000/78/ЕС про створення загальних основ рівного ставлення у сфері зайнятості та професійної діяльності (27 листопада 2000 року). URL: http://eulaw.ru/ treaties.

19 Директива 2006/54/ЕС Європейського парламенту і Ради про реалізацію принципу рівних можливостей і рівного ставлення до чоловіків та жінок у питаннях зайнятості та професійної діяльності (нова редакція) (5 липня 2006 року). URL: http://eulaw.ru/treaties

20 Заключні зауваження до восьмої періодичної доповіді України щодо виконання Україною Конвенції ООН про ліквідацію всіх форм дискримінації щодо жінок, підготовлені Комітетом ліквідації дискримінації щодо жінок. URL: http://mpe.kmu.gov.ua/minugol/ control/uk/publish/article?art_id=245331561\&cat_id $=245330359$.

21 Конституція України. URL: https://zakon.rada.gov.ua/laws/show/254\%D0\%BA/96$\% \mathrm{D} 0 \% \mathrm{~B} 2 \% \mathrm{D} 1 \% 80 \#$ Text.

22 Про забезпечення рівних прав та можливостей жінок і чоловіків : Закон України. URL: https://zakon.rada.gov.ua/laws/show/2866-15\#Text.

23 Кодекс законів про працю України. URL: https://zakon.rada.gov.ua/laws/show/322$08 \#$ Text.

\section{О. В. Агапова, Ю. Б. Шпак \\ ДО ПИТАННЯ ГЕНДЕРНОГО ДИСБАЛАНСУ У СФЕРІ ЕКС- ПЕРТНОГО ЗАБЕЗПЕЧЕННЯ ПРАВОСУДДЯ: СУЧАСНИЙ СТАН В УКРАЇНI ТА МІЖНА- РОДНИЙ ДОСВІД}

Стаття присвячена проблемі гендерної нерівності в цілому й у сфері експертного забезпечення правосуддя зокрема, а також питанню вертикальної сегрегації праці на керівних посадах у державних спеціалізованих установах України. У статті визначено можливі причини існування гендерного дисбалансу у формі вертикальної сегрегації праці на керівних посадах у сфері трудових відносин та в галузі експертного забезпечення правосуддя, а також приклади проявів гендерної нерівності. Проведено аналіз попередніх наукових досліджень видатних діячок науки i представниць інститутів громадянського суспільства щодо проблеми гендерного дисбалансу у сфері освіти, професійного самовизначення та кар'єрного зростання. Посилену увагу акцентовано на конкретних проявах гендерного дисбалансу в науці. Водночас здійснено аналіз нормативно-правових актів національного та міжнародного значення щодо подолання гендерної нерівності в різних сферах суспільного життя. Наведено міжнародно-правові акти, які мають загальний характер щодо недопущення гендерного дисбалансу, а також ті, що спрямовані на вирішення більш вузького кола питань у цій галузі. Досліджено діяльність центральних органів виконавчої влади щодо поліпшення становища жінок у суспільстві і вплив запроваджених програм на подолання гендерного дисбалансу у сфері експертного забезпечення правосуддя. Наведено показники щодо проявів можливої вертикальної сегрегації праці на керівних посадах у державних спеціалізованих установах України та приклади міжнародних організацій як таких, чия діяльність має широкий спектр впливу, так і тих, чия діяльність спрямована на поліпшення становища експерток у сфері експертного забезпечення правосуддя. Досліджено досвід таких організацій щодо недопущення та подолання гендерного дисбалансу, а також 


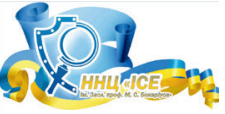

надані конкретні пропозиції для вирішення цієї проблеми.

Ключові слова: гендерний дисбаланс, гендерна рівність експертне забезпечення правосуддя, міжнародні неурядові організації.

\section{O. Agapova, Yu. Shpak}

\section{SUR LE DÉSÉQUILIBRE}

ENTRE LES SEXES DANS LE

DOMAINE D'EXÉCUTION

D'EXPERTISE JUDICIAIRE:

SITUATION ACTUELLE EN

UKRAINE ET EXPÉRIENCE

INTERNATIONALE

L'article est consacré au problème de l'inégalité entre les sexes en général et dans le domaine de d'exécution d'expertise judiciaire, en particulier, y compris le problème de la ségrégation verticale du travail dans les postes de direction dans les institutions spécialisées d'État de l'Ukraine. L'article présente les raisons possibles de l'existence d'un déséquilibre entre les sexes sous la forme d'une ségrégation verticale du travail dans les postes de direction dans le domaine des relations de travail et dans le domaine de la justice experte ainsi que des exemples d'inégalité entre les sexes. Une analyse des recherches antérieures d'éminents scientifiques et de représentants d'institutions de la société civile sur le problème du déséquilibre entre les sexes dans l'éducation, l'autodétermination professionnelle et l'évolution de carrière. Une attention particulière est accordée aux manifestations spécifiques du déséquilibre entre les sexes dans la science. Dans le même temps, une analyse des actes juridiques normatifs d'importance nationale et internationale visant à surmonter l'inégalité entre les sexes dans diverses sphères de la vie publique a été menée. Il existe des actes juridiques internationaux de nature générale visant à prévenir le déséquilibre entre les sexes ainsi que ceux visant à traiter un éventai plus restreint de problèmes dans ce domaine. On étudie l'activité des organes exécutifs centraux pour améliorer la position des femmes dans la société et l'impact des programmes mis en œuvre pour surmonter le déséquilibre entre les sexes dans le domaine de la justice. Des indicateurs sur les manifestations d'une éventuelle ségrégation verticale de la main-d'œuvre dans les postes de direction dans les institutions spécialisées d'État de l'Ukraine
GenderImbalancein the FieldofProviding Forensic Services for Justice:CurrentSituationin Ukraine and International Experience

In addition to acts guaranteeing equality between women and men, there are a number of by-laws that specify ways of improving the situation of inequality, which contain clearer provisions on achieving gender equality. For example, the State Social Program for Equal Rights and Opportunities for Women and Men until 202124, National Action Plan to implement the recommendations set out in the concluding observations of the UN Committee on the Elimination of Discrimination against Women to the eighth periodic report of Ukraine on the implementation of the Convention on the Elimination of All Forms of Discrimination against Women 202125, the National Action Plan for the implementation of UN Security Council Resolution 1325 "Women, Peace, Security" for the period up to $2025^{26}$, Gender equality strategy of The Council of Europe for 2018-202327 and others.

The United Nations Development Program, in cooperation with the Office of the Government Commissioner for Gender Policy, presented a practical guide "Gender Equality: Myths, Facts and Public Policy" for MPs, which directly points to certain forms of gender barriers ("Glass Ceiling", "Sticky floor"). Gender barriers - barriers that do not allow to achieve equal position in the labor market despite the availability of similar education and skills ${ }^{28}$.

Despite the high level of rule-making techniques of national legislation and compliance with international standards, these provisions are not always fully implemented in practice.

Manifestations of gender imbalance in the scientific sphere and the sphere of expert support of justice. One of the manifestations of gender inequality in science is the so-called "glass ceiling". "Glass ceiling" is a term used by American management to describe an invisible and formally undefined barrier that restricts a woman's promotion. Synonym - vertical gender segregation of labor. ${ }^{29}$

Regarding the phenomenon of vertical gender segregation of labor, it is necessary to firstly note some of its manifestations in the science. Researchers at Elsevier conducted a global study that resulted in a work called Gender in the Global Research Landscape. They have been researching activities in 27 areas in 12 countries for 20 years. The main conclusions of the study were:

On average, women publish less research than men, although there is no evidence that this affects the citation of their articles.

Women researchers tend to be less mobile than men internationally;

Women are less likely than men to collaborate on research in international collaboration;

Women are slightly less likely than men to collaborate on research ${ }^{30}$.

24 Про затвердження Державної соціальної програми забезпечення рівних прав та можливостей жінок і чоловіків на період до 2021 року : Постанова від 11 квітня 2018 р. № 273 Київ. Кабінет Міністрів України. URL: https://zakon.rada.gov.ua/laws/show/2732018-\% D0\%BF\#Text.

25 Про затвердження Національного плану дій з виконання рекомендацій, викладених у заключних зауваженнях Комітету ООН з ліквідації дискримінації щодо жінок до восьмої періодичної доповіді України про виконання Конвенції про ліквідацію всіх форм дискримінації щодо жінок на період до 2021 року: Розпорядження від 5 вересня 2018 р. № 634-p Київ. URL:https:/ / zakon.rada.gov.ua/laws/show/273-2018-\%D0\%BF\#Text.

26 Про затвердження Національного плану дій з виконання резолюції Ради Безпеки ООН 1325 “Жінки, мир, безпека” на період до 2025 року : Розпорядження від 28 жовтня 2020 р. № 1544-p Київ. Кабінет Міністрів України. URL : https://zakon.rada.gov.ua/laws/ show $/ 1544-2020-\%$ D1\%80\#Text.

27 Стратегія гендерної рівності ради Європи на 2018-2023 роки. Рада Європи. URL: https:/ / rm.coe.int/prems-041318-gbr-gender-equality-strategy-2023-ukr-new2/16808b35a4.

28 Гендерна рівність: міфи, факти та державна політика Посібник для народних депутатів України. URL: https://www.ua.undp.org/content/ukraine/uk/home/library/democratic_ governance/gender-equality-handbook-for-mps.html

29 Шевченко 3. В. (2016). Словник гендерних термінів. Черкаси: видавець Чабаненко Ю. URL: http:/ /a-z-gender.net/ua/sklyana-stelya.html

30 Gender in the Global Research Landscape // Elsevier: URL: https://www.elsevier.com/_ data/assets/pdf_file/0008/265661/ElsevierGenderReport_final_for-web.pdf. 
Some of these conclusions seem questionable to us, but despite this, gender imbalances still remain a factor influencing gender imbalances in the scientific field.

Thus, a manifestation of gender imbalance in the form of vertical segregation of labor and a negative trend in its minimization is the absence of women in the management of enterprises, institutions and organizations.

A similar phenomenon is observed in almost all systems of state specialized institutions of Ukraine, for example, in the State Research Forensic Center and 24 territorial institutions of the Research Forensic Center of the Ministry of Internal Affairs of Ukraine (hereinafter - MIA) no woman holds a managerial position, despite the general trend of improving the situation of women in Ukraine ${ }^{31}$ and the activities of the MIA to ensure gender equality. Thus, a study was conducted on "Understanding masculinity in the security sector of Ukraine" with the support of the UN Office "Women in Ukraine" in 2018. In 2020, MIA and the consortium "NIRAS" SwedenAB signed a Memorandum of Cooperation within the project "Gender Budgeting in Ukraine" ${ }^{32}$..

A detailed analysis of forensic research institutions of the Ministry of Justice of Ukraine allowed to obtain such statistical information. There are 27 institutions of the Ministry of Justice in the system of forensic research institutions, in which 20 men and, accordingly, 7 women hold the position of director ${ }^{33}$.

It is worth noting that this positive trend is explained by the fact that the Ministry of Justice is taking a set of in-depth measures to overcome the manifestations of gender imbalance.

In accordance with paragraph 13 of the Resolution of the Cabinet of Ministers of Ukraine of November 28, 2018 № 997 "Issues of gender legal examination" Gender legal examination of draft regulations is conducted by the Ministry of Justice during the legal examination ${ }^{34}$. In order to identify cases of gender discrimination by the Order of the Ministry of Justice of Ukraine dated 12.03.2019 №33 On approval of the Guidelines for the identification of cases of gender discrimination and the mechanism for providing legal assistance ${ }^{35}$. Particular attention should be paid to the participation in the project of international technical assistance in the gender equality in cooperation with the Swedish Agency for International Cooperation and Development. This project focuses on assistance in the field of gender equality, overcoming structural barriers to gender equality and women's rights, as well as strengthening cross-sectoral cooperation and oversight in the field of gender equality and women's rights ${ }^{36}$.

At the same time, on the positive side, it should be noted that in the period from 2018 to 2020, the Ministry of Justice was the coordinator of the Action

з1 Експертна служба МВС - НДЕКЦ - Територіальні підрозділи. URL: https:/ / dndekc.mvs.gov ua $\%$ d0 $\%$ b5 $\%$ d0 $\%$ ba $\%$ d $1 \% 81 \%$ d0 $\%$ bf $\%$ d0 $\%$ b5 $\%$ d $1 \% 80 \%$ d $1 \% 82 \%$ d0 $\%$ bd $\%$ d0 $\%$ b0- $\%$ d $1 \% 81 \%$ d 0 \%bb \%d1\%83\%d0\%b6\%d0\%b1\%d0\%b0-\%d0\%bc\%d0\%b2\%d1\%81/\%d0\%bd \%d0\%b4 \%d0\%b5\%

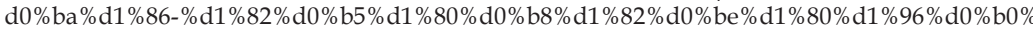

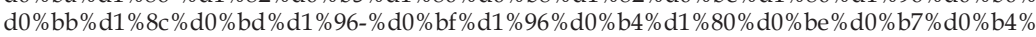
$\mathrm{d} 1 \% 96 \% \mathrm{~d} 0 \% \mathrm{bb} \% \mathrm{~d} 0 \% \mathrm{~b} 8 /$.

32 Камінська Н. В., Чернявський С. С., Перунова О. С. Забезпечення гендерної рівності в системі МВС та інших центральних органів виконавчої влади : лекція. Київ : Нац. акад. внутр. справ, 2020. С. 13, 20.

33 НАУКОВО-ДОСЛІДНІ УСТАНОВИ СУДОВИХ ЕКСПЕРТИЗ. URL: https:/ / minjust.gov.ua/ section_8

34 Питання проведення гендерно-правової експертизи : Постанова Кабінету Міністрів України від 28 листопада 2018 р. № 997. URL: https:// zakon.rada.gov.ua/laws/show/9972018-\%D0\%BF\#Text.

35 Про затвердження Методичних рекомендацій щодо ідентифікації випадків гендерної дискримінації та механізм надання правовоїдопомоги: Наказ Міністерства юстиції України від 12.03.2019 № 33. URL: https://zakononline.com.ua/documents/show/112397_112397.

36 Transition Book. Міністерство юстиції України. URL: https://minjust.gov.ua/files/gener al/2019/09/10/20190910154815-24.pdf.

sont donnés. Il existe des exemples d'organisations internationales, à la fois celles dont les activités ont un large éventail d'influence et celles dont les activités visent à améliorer la position des experts dans le domaine de l'expertise judiciaire. L'expérience de ces organisations dans la prévention et la résolution des déséquilibres entre les sexes a été étudiée et des propositions spécifiques ont été faites pour résoudre ce problème.

Mots-clés: déséquilibre entre les sexes, égalité des sexes, soutien d'experts à la justice, organisations non

internationales. gouvernementales

\section{Е. В. Агапова, Ю. Б. Шпак}

\section{К ВОПРОСУ ГЕНДЕРНОГО}

ДИСБАЛАНСА В

СФЕРЕ ЭКСПЕРТНОГО

ОБЕСПЕЧЕНИЯ

ПРАВОСУДИЯ:

СОВРЕМЕННОЕ

СОСТОЯНИЕ В УКРАИНЕ И

МЕЖДУНАРОДНЫЙ ОПЫТ

Статья посвящена проблеме гендерного неравенства в целом и в сфере экспертного обеспечения правосудия в частности, а также вопросу вертикальной сегрегации труда на руководящих должностях в государственных с пе ци ал и зи ров анных учреждениях Украины. статье определены возможные причины существования гендерного дисбаланса в форме вертикальной сегрегации труда на руководящих должностях в сфере трудовых отношений и в области экспертного обеспечения правосудия, а также примеры проявлений гендерного неравенства. Проведен анализ предыдущих научных исследований выдающихся деятельниц науки и представительниц институтов гражданского общества относительно проблемы гендерного дисбаланса в сфере образования, профессионального самоопределения и карьерного роста. Усиленное внимание акцентировано на конкретных проявлениях гендерного дисбаланса в науке. Наряду с тем осуществлен анализ нормативноправовых актов национального и международного значения относительно преодоления гендерного неравенства в различных сферах общественной жизни. Приведены международно-правовые акты, которые имеют общий характер 


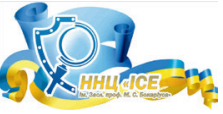

относительно недопущения гендерного дисбаланса, а также те, которые направлены на решение более узкого круга вопросов в этой области. Исследованы деятельность центральных органов исполнительной власти относительно улучшения положения женщин в обществе и влияние введенных программ на преодоление гендерного дисбаланса в сфере экспертного обеспечения правосудия. Приведены показатели относительно проявлений возможной вертикальной сегрегации труда на руководящих должностях в государственных с п е и л и 3 и ро в ан ны учреждениях Украины и примеры международных организаций - как таких, чья деятельность имеет широкий спектр воздействия, так и тех, чья деятельность направлена на улучшение положения экспертов в сфере экспертного обеспечения правосудия. Исследован опыт таких организаций по предупреждению и преодолению гендерного дисбаланса, а также предоставлены конкретные предложения для решения этой проблемы.

Ключевые слова: гендерный дисбаланс, гендерное равенство, экспертное правосудия обеспечение международные н е п ра в и т ел ь с т е н ны е организации.

\section{O. Agapova, Yu. Shpak}

ÜBER DIE

GESCHLECHTERUNGLEICHHEIT IN EXPERTENSICHERSTELLUNG DER JUSTIZ: AKTUELLE

SITUATION IN DER UKRAINE UND INTERNATIONALE ERFAHRUNG

Die Zusammenfassung des Artikels. Der Artikel widmet sich dem Problem der Geschlechterungleichheit im Allgemeinen und im Bereich der Expertensicherstellung der Justiz im Besonderen, einschließlich des Problems der vertikalen Arbeitssegregation in Führungspositionen in staatlichen Facheinrichtungen der Ukraine. Die Abhandlung setzt mögliche Ursachen für die Geschlechterungleichheit in Form einer vertikalen Arbeitssegregation in Führungspositionen im Bereich der Arbeitsbeziehungen und Expertensicherstellung der Justiz sowie Beispiele für Ausprägungen der Geschlechterungleichheit auseinander. Man führt die Analyse

Plan for the implementation of the National Human Rights Strategy until 2020, and on March 21, 2018 the Ministry of Justice signed a Memorandum of Understanding from the UN Women in Ukraine ${ }^{37}$.

The influence of international organizations on achieving gender equality in providing forensic services for justice. International organizations impact in achieving gender equality in the field of forensic science service providing. The most authoritative organizations that deal with redressing women situation in different areas of social life should be mentioned are United Nations Entity for Gender Equality and the Empowerment of Women (hereinafter - UN Women), International Bureau of Education (hereinafter - IBE UNESCO), and Organisation for Economic Co-operation and Development (hereinafter - OECP).

UN Programmes aim to cooperation outreach for male and female representatives of private business, science, non-profit organizations to accelerate the achievement of gender equality, identifying key barriers that impede the promotion of women and girls in the науки та інновацій, технологій, підприємництва; співпраця задля виявлення та вжиття заходів для подолання таких бар'єрів ${ }^{38}$.

The purpose of International Bureau of Education (IBE-UNESCO) is to support and promote problem solving, and faced by ministries of education and governments in an effort to achieve equality in education and science and by improving curriculum as well as teaching, learning and assessment processes in line with the principle of respect for human rights ${ }^{39}$.

OECP directs its activities to strengthen and improve the efficiency of the economies of the member states, improve social and economic conditions and employment situation, ensure economic growth of both industrialized and developing countries ${ }^{40}$. In the field of combating gender inequality, the OECP monitors the wage difference between women and men for the same work done and has launched a gender-based initiative to monitor the fields of education, employment and entrepreneurship ${ }^{41}$.

These regional organizations carry out a wide range of measures aimed at improving the situation of women in science and other areas of social life. However, to minimize gender imbalance in the field of providing forensic science services for justice, there are also specialized organizations that take measures to familiarize the forensic community with the gender inequality problem and ways to overcome it.

Association of Women in Forensic Science and Worldwide Association of Women Forensic Experts are the organizations with more focused specialization. Their purpose is to cooperate with women in forensic science institutes.

Association of Women in Forensic Science based in the USA and primarily engaged in educational activities. Their primary goal is to provide networking opportunities, resources, and programs to female college students, forensic professionals, and youth. Through their efforts, they have connected communities with forensic science resources that have successfully broadened their understanding of the forensic science field ${ }^{42}$.

\footnotetext{
37 Міністерство юстиції посилюе діяльність щодо впровадження гендерної рівності // Міністерство Юстиції України. 2018. URL: https://minjust.gov.ua/news/ministry/ ministerstvo-yustitsii-posilyue-diyalnist-schodo-vprovadjennya-\%D2\%91endernoi-rivnosti.

38 The United Nations Entity for Gender Equality and the Empowerment of Women (UN Women) // UNITED NATIONS .URL: https://www.unwomen.org/en.

39 About us IBE-UNESCO. URL: http://www.ibe.unesco.org/en

40 Організація економічного співробітництва та розвитку. URL: https://mfa.gov.ua/ mizhnarodni-vidnosini/organizaciya-ekonomichnogo-spivrobitnictva-ta-rozvitku.

${ }^{41}$ The OECD Gender Initiative URL: https://www.oecd.org/gender/.

42 Welcome to AWIFS: Providing opportunities for youth to learn about forensic science. URL: https://awifs.org/about/.
} 
WAWFE is a multi-disciplinary association with the aim of connecting women working worldwide in different forensic fields, in public or private institutions, in order to promote the advancement and recognition of the role of women in the international forensic community and to facilitate the information and experience exchange between forensic experts ${ }^{43}$.

The activities of the aforementioned organizations contribute to solving the problem of gender imbalance by attracting attention to it, identifying specific manifestations of gender inequality, involving women in cooperation and creating programs for women's cooperation, as well as educational activities for girls.

We are deeply convinced that the activities of such NGOs that bring women together - experts could contribute to the improvement of the situation with gender inequality in the field of providing forensic science services for justice in Ukraine in case of their creation and in the case of the participation of Ukrainian experts in such organizations.

Conclusions. The problem of minimizing and overcoming gender imbalances in scientific institutions of Ukraine requires a deeper study. Currently, the best option for adopting international experience for Ukraine to solve this problem is as follows:

1. The problem of gender imbalance was investigated in various aspects by many male and female scientists, but the topic of gender imbalance in the field of providing forensic science services for justice.

2. The inadmissibility of gender imbalance is regulated by current international and national law, which do not find sufficient implementation in the field of providing forensic science services for justice.

3. Vertical segregation of labor is observed in the research institutions of forensic examinations of the Ministry of Internal Affairs, which may be explained by the fact that the Ministry of Internal Affairs lacks measures and programs, including in cooperation with other institutions and organizations that would be aimed at improving the situation of women in the field of providing forensic science services for justice. Regarding the manifestations of gender inequality in the field of providing forensic science services for justice, it is worth noting the activities of the Ministry of Justice to improve the situation of women, including women experts. However, statistical indicators still indicate the existence of such a problem in the research institutions of forensic examinations of the Ministry of Justice.

4. A promising direction of overcoming this situation may be the creation of specialized organizations that would bring together women experts to raise awareness of the problem itself, to conduct joint events and programs, to increase professionalism to overcome gender inequality in the field of providing forensic science services for justice, etc.

\section{References}

About us IBE-UNESCO URL: http://www.ibe.unesco.org/en [in English].

Gender in the Global Research Landscape. Elsevier. URL: https://www.elsevier. com/__data/assets/pdf_file/0008/265661/ElsevierGenderReport_final_for-web. pdf [in English].

The OECD Gender Initiative URL: https://www.oecd.org/gender/ [in English].

The United Nations Entity for Gender Equality and the Empowerment of Women (UN Women). UNITED NATIONS. URL: https://www.unwomen.org/en. [in English].

Transition Book. Ministry of Justice of Ukraine. URL: https://minjust.gov.ua/files/ge neral/2019/09/10/20190910154815-24.pdf [in English].

Welcome to AWIFS: Providing opportunities for youth to learn about forensic science. URL: https://awifs.org/about/ [in English].

43 Worldwide Association of Women Forensic Experts (WAWFE). URL: https:/ / www.wawfe.org/ About.htm.

vorheriger Forschungen von prominenten Wissenschaftlerinnen und Vertreterinnen $\mathrm{zivilgesellschaftlicher}$ Institutionen zum Problem der Geschlechterungleichheit in der Bildung, beruflichen Selbstbestimmung und Karriereentwicklung durch Besonderes Augenmerk wird auf spezifische Erscheinungsformen der Geschlechterungleichheit in der Wissenschaft gelegt. Gleichzeitig wird die Analyse normativer Rechtsakte von nationaler und internationaler Bedeutung zur Überwindung der Geschlechterungleichheit in verschiedenen Bereichen des Gesellschaftslebens durchgeführt. Man berichtet über allgemeine internationale Rechtsakte zur Verhinderung der Geschlechterungleichheit und über solche, die auf die Lösung des engeren Spektrums von Themen in diesem Bereich abzielen. Die Aktivitäten zentraler Exekutivorgane zur Verbesserung der Position von Frauen in der Gesellschaft und die Auswirkungen der durchgeführten Programme auf die Überwindung der Geschlechterungleichheit im Bereich der Expertensicherstellung der Justiz werden untersucht. Es werden Indexe für eine mögliche vertikale Arbeitssegregation in Führungspositionen in staatlichen spezialisierten Facheinrichtungen der Ukraine gegeben. Es gibt Beispiele für internationale Organisationen, sowohl solche, deren Aktivitäten einen breiten Einflussbereich haben, als auch solche, deren Aktivitäten darauf abzielen, die Position von Expertinnen in der Expertensicherstellung der Justiz zu verbessern. Man untersucht die Erfahrungen solcher Organisationen bei der Nichtzulassung und Überwindung der Geschlechterungleichheit und machte konkrete Vorschläge zur Lösung dieses Problems.

$\mathrm{S}$ c h l ü s s e $1 \mathrm{w}$ ö $\mathrm{r}$ te $\mathrm{r}$ : Genderungleichgewicht, Gleichstellung der Geschlechter, Expertensicherstellung der Justiz, internationale Nichtregierungsorganisationen. 
Funding

This research did not receive any specific grant from funding agencies in the public, commercial, or not-for-profit sectors.

\section{Disclaimer}

The funders had no role in the study design, data collection and analysis, decision to publish, or preparation of the manuscript.

\section{Contributors}

The authors contributed solely to the intellectual discussion underlying this paper, case-law exploration, writing and editing, and accept responsibility for the content and interpretation.

\section{Declaration of Competing} Interest

The authors declare that they have no conflict of interest.
Worldwide Association of Women Forensic Experts (WAWFE). URL: https://www. wawfe.org/About.htm [in English].

Genderna rivnist': mify, fakty ta derzhavna polityka (Eng. Gender equality: myths, facts and state policy Handbook members of parliament of Ukraine): Posibnyk dlya narodnykh deputativ Ukrayiny. URL: https://www.ua.undp.org/content/ ukraine/uk/home/library/democratic_governance/gender-equality-handbookfor-mps.html [in Ukrainian].

Gendernoe ravenstvo. Orhanyzatsyya Ob'edynennykh Natsyy (Eng. Gender equality. United Nations). 2021. URL: https://www.un.org/ru/sections/issues-depth/ gender-equality/ [in Russian].

Dashkovs'ka, O. R. (2014) Pryntsyp gendernoyi rivnosti: ponyattya, vytoky i rol' na suchasnomu etapi rozvytku suspil'stva (Eng. Gender equality: concepts, origins and role at the present stage of development of society). Porivnyal'no-analitychne pravo. № 5. P. 20-23. [in Ukrainian].

Dyrektyva 2006/54/ES Yevropeys'koho parlamentu i Rady pro realizatsiyu pryntsypu rivnykh mozhlyvostey i rivnoho stavlennya do cholovikiv ta zhinok u pytannyakh zaynyatosti ta profesiynoyi diyal'nosti /nova redaktsiya (Eng. Directive 2006/54/ EC of the European Parliament and of the Council on the implementation of the principle of equal opportunities and equal treatment of men and women in matters of employment and occupation). 05 lypnya 2006 roku. URL: http://eulaw. $\mathrm{ru}$ /treaties [in English].

Dyrektyva Rady 2000/78/ES pro stvorennya zahal'nykh osnov rivnoho stavlennya u sferi zaynyatosti ta profesiynoyi diyal'nosti (Eng. Council Directive 2000/78/EC on establishing of common framework for equal treatment in employment and occupation). 27 lystopada 2000 roku. URL: http://eulaw.ru/treaties [in English].

Ekspertna sluzhba MVS - NDEKTS - Terytorial'ni pidrozdily (Eng. Expert Service Of The MIA - SRFCs- Territorial subdivisions). URL: https://dndekc.mvs.gov.ua/експертна-служба-мвс/ндекц-територіальні-підрозділи/ [in Ukrainian].

Yevropeys'ka sotsial'na khartiya (Eng. European Social Charter). URL: https://zakon. rada.gov.ua/laws/show/994_062\#Text [in Ukrainian].

Zhinka v nautsi ta osviti: mynule, suchasnist', maybutnye (Eng. Woman in science and education: past, present, future). Materialy Mizhnarodnoyi naukovopraktychnoyi konferentsiyi. K.: 1999, 2002, 2005, 2008, 2011. ISBN 966-95382-2-X; ISBN 966-95382-3-X; ISBN 966-9582-7-0; ISBN 978-617-615-007-7 [in Ukrainian].

Zhukovs'ka, H. H. \& Levchenko, K. B. \& Ostapenko, O. O. \& Suslova, O.I. (2016) Genderna polityka v normatyvno-pravovykh dokumentakh (Eng. Gender policy in laws and regulations). URL: https://www.kmu.gov.ua/storage/app/ sites/1/18\%20-\%20Department/18\%20-\%20PDF/02.2021/genderna-polityka.pdf [in Ukrainian].

Zahal'na deklaratsiya prav lyudyny (Eng. Universal Declaration of Human Rights). URL: https://zakon.rada.gov.ua/laws/show/995_015\#Text [in Ukrainian].

Zaklyuchni zauvazhennya do vos'moyi periodychnoyi dopovidi Ukrayiny shchodo vykonannya Ukrayinoyu Konventsiyi OON pro likvidatsiyu vsikh form dyskryminatsiyi shchodo zhinok, pidhotovleni Komitetom likvidatsiyi dyskryminatsiyi shchodo zhinok (Eng. Concluding Observations to the Eighth Periodic Report of Ukraine on Ukraine's Implementation of the UN Convention on the Elimination of All Forms of Discrimination against Women, prepared by the Committee on the Elimination of Discrimination against Women). URL: http:// mpe.kmu.gov.ua/minugol/control/uk/publish/article?art_id=245331561\&cat_ id=245330359 [in Ukrainian].

Isakova, N. B. (2018) Gendernyy parytet u nautsi: tendentsiyi v sviti ta v Ukrayini (Eng. Gender parity in science: trends in the world and in Ukraine). Nauka ta naukoznavstvo. № 2. P. 68-90. [in Ukrainian].

Kamins'ka, N. V. (2020) Chernyavs'kyy S. S, Perunova O. S. Zasady rozuminnya genderu ta gendernoyi rivnosti (Eng. Principles of understanding gender and gender equality). URL: https://www.dsns.gov.ua/files/2020/5/20/112/Лекція_1. pdf [in Ukrainian]. 
Kamins'ka, N. V. \& Chernyavs'kyy, S. S. \& Perunova, O. S. (2020) Zabezpechennya gendernoyi rivnosti $\mathrm{V}$ systemi MVS ta inshykh tsentral'nykh orhaniv vykonavchoyi vlady (Eng. Ensuring gender equality in the system of the Ministry of Internal Affairs and other central executive bodies): lektsiya. Kyiv. Nats. akad. vnutr. sprav. 31 p. [in Ukrainian].

Kamins'ka, N. \& Svyeshnikova, M. (2020) Diyal'nist' mizhnarodnykh orhanizatsiy u sferi zabezpechennya gendernoyi rivnosti (Eng. Activities of international organizations in the field of gender equality). URL: https://scholar. google.com.ua/citations? user=yeAhqYsAAAAJ\&hl=ru\#d=gs_md_cita$\mathrm{d} \& \mathrm{u}=\% 2 F$ citations\%3Fview_op\%3Dview_citation\%26hl\%3Dru\%26user\%3DyeAhq YsAAAAJ\%26cstart\%3D20\%26pagesize\%3D80\%26citation_for_view\%3DyeAhqYs AAAAJ\%3ACHSYGLWDkRkC\%26tzom\%3D-180 [in Ukrainian].

Kateryna Levchenko (2018) Instytutsional'nyy mekhanizm realizatsiyi derzhavnoyi polityky zabezpechennya rivnykh prav ta mozhlyvostey zhinok i cholovikiv: aktual'nyy stan, problemy, perspektyvy rozvytku (Eng. Institutional mechanism of implementing the state policy of ensuring equal rights and opportunities for women and men: current status, problems, development prospects). URL: https:// www.publichne-pravo.com.ua/files/31/23.pdf [in Ukrainian].

Kodeks zakoniv pro pratsyu Ukrayiny (Eng. Labor Code of Ukraine). URL: https:// zakon.rada.gov.ua/laws/show/322-08\#Text [in Ukrainian].

Konventsiya Orhanizatsiyi Ob'yednanykh Natsiy pro likvidatsiyu vsikh form dyskryminatsiyi shchodo zhinok (Eng. United Nations Convention on the Elimination of All Forms of Discrimination against Women). URL: https://zakon. rada.gov.ua/laws/show/995_207\#Text [in Ukrainian].

Konventsiya pro zakhyst prav lyudyny i osnovopolozhnykh svobod (Eng. Convention for the Protection of Human Rights and Fundamental Freedoms). URL: https:// zakon.rada.gov.ua/laws/show/995_004\#Text [in Ukrainian].

Konstytutsiya Ukrayiny (Eng. Constitution of Ukraine). URL: https://zakon.rada.gov. ua/laws/show/254\%D0\%BA/96-\%D0\%B2\%D1\%80\#Text [in Ukrainian].

Libanova, E. M. \& Makarova, O.V. (1998) Dostup zhinok do rynku pratsi: sytuatsiya s'ohodennya ta mozhlyvosti roz shyrennya (Eng. Women's access to the labor market: the current situation and opportunities for expansion). Mat. nats. trystoronn'oyi konf. "Zhinky na rynku pratsi Ukrayiny". Kyiv. [in Ukrainian].

Mizhnarodnyy pakt pro hromadyans'ki i politychni prava (Eng. International Covenant on Civil and Political Rights). URL: https://zakon.rada.gov.ua/laws/ show/995_043\#Text [in Ukrainian].

Mizhnarodnyy pakt pro ekonomichni, sotsial'ni i kul'turni prava (Eng. International Covenant on Economic, Social and Cultural Rights). URL: https://zakon.rada.gov. ua/laws/show/995_042\#Text [in Ukrainian].

Ministerstvo Yustytsiyi posylyuye diyal'nist' shchodo vprovadzhennya gendernoyi rivnosti (Eng. The Ministry Of Justice Strengthens Activities For The Implementation Of Gender Equality). Ministerstvo Yustytsiyi Ukrayiny. 2018. URL: $\quad$ https://minjust.gov.ua/news/ministry/ministerstvo-yustitsii-posilyuediyalnist-schodo-vprovadjennya-\%D2\%91endernoi-rivnosti [in Ukrainian].

Naukovo-doslidni ustanovy sudovykh ekspertyz (Eng. Research Institutions Of Forensic Examinations). URL: https://minjust.gov.ua/section_8 [in Ukrainian].

Shevchenko, Z.V. (2016) Orhanizatsiya ekonomichnoho spivrobitnytstva ta rozvytku (Eng. Organization of economic cooperation and development). URL: https://mfa. gov.ua/mizhnarodni-vidnosini/organizaciya-ek URL: http://a-z-gender.net/ua/ sklyana-stelya.html [in Ukrainian].

Received by Editorial Board: 22.05.2021

Suggested Citation:

Agapova, O., Shpak, Yu. (2021). Gender imbalance in the field of providing forensic services for justice: current situation in Ukraine and international experience. Archives of Criminology and Forensic Sciences. 1(3). 39-47. DOI: https://doi. org/10.32353/acfs.3.2021.03. 